\title{
Comparing Chitin-urea to Other Materials for Control of Northern Root-knot Nematode on Paprika Pepper
}

\author{
Brian A. Kahn', John P. Damicone², Kenneth E. Jackson ${ }^{3}$, \\ James E. Motes ${ }^{4}$, and Mark E. Payton ${ }^{5}$ \\ Oklahoma State University, Stillwater, OK 74078
}

Additional index words. Capsicum annuum, Meloidogyne hapla, nematicides

\begin{abstract}
Nine nematicide treatments were evaluated from 1993 through 1995 in field experiments on paprika pepper (Capsicum annuum L.). Materials tested included a chitinurea soil amendment and six chemicals: fosthiazate, carbofuran, aldicarb, oxamyl, fenamiphos, and 1,3-dichloropropene (1,3-D). Stands at harvest were increased relative to the control by chitin-urea, fosthiazate, and 1,3-D, but only fosthiazate increased marketable fruit yield relative to the control. Aldicarb reduced preharvest nematode populations relative to the control, but aldicarb did not result in a significant fruit yield increase. Chitin-urea was the only treatment to produce a net increase in nematode counts from preplant to preharvest in all three years. Although fosthiazate was promising, nematicide treatments were of limited benefit under the conditions of these studies. Chemical names used: $(R S)$-S -sec-butyl $O$-ethyl 2-oxo-1,3-thiazolidin-3- ylphosphonothioate (fosthiazate); 2,3-dihydro-2,2-dimethyl-7-benzofuranyl methylcarbamate (carbofuran); 2-methyl-2(methylthio)propionaldehyde $O$-(methylcarbamoyl)oxime (aldicarb); methyl $N^{\prime} N^{\prime}$-dimethyl- $N$-[(methylcarbamoyl)oxy]-1-thiooxamimidate (oxamyl); ethyl 3-methyl-4(methylthio)phenyl(1-methylethyl) phosphoramidate (fenamiphos).
\end{abstract}

The northern root-knot nematode (Meloidogyne hapla Chitwood) is often present in fields repeatedly planted to peanuts (Arachis hypogaea L.). Damage from $M$. hapla has been observed on paprika peppers planted as an alternative crop in rotation with peanuts. There is interest in less toxic alternatives to the chemical nematicides labeled for peppers. Nine nematicide treatments were evaluated from 1993 through 1995 in field experiments on 'Oklahoma Paprika 50' pepper. Materials tested included a chitin-urea soil amendment (ClandoSan; IGENE Biotechnology, Columbia, Md.) and six chemicals: fosthiazate, carbofuran, aldicarb, oxamyl, fenamiphos, and 1,3-D.

\section{Materials and Methods}

Studies were conducted at the Caddo Research Station, Fort Cobb, Okla., on a Meno loamy fine sand (loamy, mixed, superactive, thermic Aquic Arenic Haplustalfs). Different fields were used each year, but all had previously been cropped to peanuts. Weeds were controlled with preplantincorporated napropamide ([N,N-diethyl-2-(1naphthaleneyloxy)-propionamide]) at 2.2 $\mathrm{kg} \cdot \mathrm{ha}^{-1}$ and cultivation. Sprinkler irrigation was used as required. Preplant-incorporated fertilizers were $56 \mathrm{~N}-25 \mathrm{P}-46 \mathrm{~K}\left(\mathrm{~kg} \cdot \mathrm{ha}^{-1}\right)$ in 1993 and 1994, and $38 \mathrm{~kg} \cdot \mathrm{ha}^{-1}$ of $\mathrm{N}$ in 1995. One topdressing of $56 \mathrm{~kg} \cdot \mathrm{ha}^{-1}$ of $\mathrm{N}$ was made each year at first fruit set. Peppers were direct seeded on 14 May 1993, 19 Apr. 1994, and 27 Apr. 1995 at $2-3 \mathrm{~kg} \cdot \mathrm{ha}^{-1}$. Plots were $12 \mathrm{~m}$ long and four rows wide, with $0.9 \mathrm{~m}$ between rows.

The design was a randomized complete block with four replications. Nematicides were preplant-incorporated with a rototiller to a depth of 5-10 $\mathrm{cm}$ in a band $30 \mathrm{~cm}$ wide $(45 \mathrm{~cm}$ wide for chitin-urea) over each row, except for 1,3-D which was injected $25 \mathrm{~cm}$ deep through a single chisel per row and sealed by packing. Application dates were 2 Apr. 1993, 31 Mar. 1994, and 6 Apr. 1995 for chitin-urea; 19 Apr. 1993, 19 Apr. 1994, and 20 Apr. 1995 for fosthiazate, carbofuran, aldicarb, oxamyl, and fenamiphos; and 6 Apr. 1993, 31 Mar. 1994, and 6 Apr. 1995 for 1,3-D. Rates of application are shown in Table 1. Supplemental foliar sprays of oxamyl were applied through three directed nozzles per row providing $280 \mathrm{~L} \cdot \mathrm{ha}^{-1}$ of spray at $2.8 \mathrm{~kg} \cdot \mathrm{cm}^{-2}$ (40 psi). Oxamyl was applied at $0.55 \mathrm{~kg} \cdot \mathrm{ha}^{-1}$ per application on 21 July, 13 Aug., 26 Aug., and 16 Sept. 1993; 20 July, 4 Aug., and 29 Aug. 1994; and 27 June, 21 July, and 1 Sept. 1995.

Root-knot nematode populations were determined by collecting 10 soil cores $(2.0 \mathrm{~cm}$ in diameter $\times 20 \mathrm{~cm}$ deep) from each plot. Cores were bulked and second-stage juveniles were extracted from a $100-\mathrm{cm}^{3}$ subsample using the bucket-decanting, Baermann funnel method (Ayoub, 1980). Preplant samples averaged 23 $M$. hapla per $100 \mathrm{~cm}^{3}$. The overall $\mathrm{F}$ test for treatment differences in preplant nematode counts was not significant $(P \geq 0.05$; analysis not presented). Most soil samples taken in July of each year did not contain any second-stage nematodes. Preharvest nematode sampling was done on 20 Oct. 1993, 18 Oct. 1994, and 13 Nov. 1995.

Peppers were harvested after a frost in each year per grower practice. Dates of harvest were 10 Nov. 1993, 22 Nov. 1994, and 13 Nov. 1995. Yield was determined from each plot by selecting $2.5 \mathrm{~m}$ in 1993 and 1994 and $3 \mathrm{~m}$ in 1995 from one of the two center rows. Plants were cut off by hand at soil level, counted, and defruited. Fruits were graded as marketable (deep red) or cull and dried at $48{ }^{\circ} \mathrm{C}$ for at least $7 \mathrm{~d}$ before weighing.
Received for publication 10 Dec. 2001. Accepted for publication $12 \mathrm{Apr}$. 2002. Approved for publication by the Director, Oklahoma Agricultural Experiment Station. This research was supported in part under project $\mathrm{H}-2026$. The information given in this publication is for educational purposes only. Mention of a trademark, proprietary product, or vendor does not constitute a guarantee or warranty of the product, nor does it imply approval or disapproval to the exclusion of other products or vendors that may also be suitable.

${ }^{1}$ Professor, Dept. of Horticulture and Landscape Architecture, and corresponding author.

${ }^{2}$ Professor, Dept. of Entomology and Plant Pathology.

${ }^{3}$ Assistant Extension Specialist, Dept. of Entomology and Plant Pathology.

${ }^{4}$ Professor Emeritus, Dept. of Horticulture and Landscape Architecture.

${ }^{5}$ Professor, Dept. of Statistics.
Table 1. Stand and yield of paprika peppers and northern root-knot nematode population in response to various materials/rates, Fort Cobb, Okla., 1993-95.

\begin{tabular}{|c|c|c|c|c|}
\hline \multirow[b]{2}{*}{ Treatment } & \multirow[b]{2}{*}{ Rate $^{z}$} & \multicolumn{2}{|c|}{ Peppers } & \multirow{2}{*}{$\begin{array}{c}\text { Nematodes } \\
\text { Population before } \\
\text { pepper harvest } \\
\left(\text { no. } / 100 \mathrm{~cm}^{3}\right)\end{array}$} \\
\hline & & $\begin{array}{c}\text { Stand at } \\
\text { harvest } \\
\text { (plants/m) }\end{array}$ & $\begin{array}{c}\text { Marketable } \\
\text { fruit dry wt } \\
\left(\mathrm{g} \cdot \mathrm{m}^{-2}\right)\end{array}$ & \\
\hline Control & --- & 15 & 63 & 28 \\
\hline Chitin-urea & $2242 \mathrm{~kg} \cdot \mathrm{ha}^{-1}$ & $22^{*}$ & 77 & 50 \\
\hline Fosthiazate & Varied ${ }^{y}$ & $19^{*}$ & $94^{*}$ & 7 \\
\hline Carbofuran & $2.24 \mathrm{~kg} \cdot \mathrm{ha}^{-1}$ & 15 & 67 & 13 \\
\hline Aldicarb & $2.52 \mathrm{~kg} \cdot \mathrm{ha}^{-1}$ & 16 & 85 & $4^{*}$ \\
\hline Oxamyl ${ }^{x}$ & $0.56 \mathrm{~kg} \cdot \mathrm{ha}^{-1}$ & 16 & 76 & 9 \\
\hline Fenamiphos & $1.51 \mathrm{~kg} \cdot \mathrm{ha}^{-1}$ & 15 & 71 & 28 \\
\hline Fenamiphos & $2.24 \mathrm{~kg} \cdot \mathrm{ha}^{-1}$ & 16 & 72 & 13 \\
\hline $1,3-\mathrm{D}$ & $56.1 \mathrm{~L} \cdot \mathrm{ha}^{-1}$ & $19^{*}$ & 87 & 10 \\
\hline $1,3-\mathrm{D}$ & $112.2 \mathrm{~L} \cdot \mathrm{ha}^{-1}$ & $20^{*}$ & 86 & 18 \\
\hline
\end{tabular}

${ }^{\mathrm{z}}$ Rates are actual materials for chitin-urea and 1,3-D and active ingredients otherwise.

y $2.24 \mathrm{~kg} \cdot \mathrm{ha}^{-1}$ in 1993 and $1995 ; 3.36 \mathrm{~kg} \cdot \mathrm{ha}^{-1}$ in 1994.

${ }^{x}$ Supplemental foliar sprays also were applied; see text for details.

*Indicates a mean in columns that differs from the control by least squares, $P \leq 0.05$ 
Data were analyzed separately for each year, but overall $\mathrm{F}$ tests for treatments were not significant (data not presented). Data were pooled and analyzed again using a model with two sources of variation: replications within years and treatments. Planned contrasts of treatment means to the control were made using an LSMEANS statement in the Statistical Analysis System (SAS) (SAS Institute, 1999) with a PDIFF option and a significance level of 0.05 .

\section{Results and Discussion}

Four treatments increased stand at harvest relative to the control: chitin-urea, fosthiazate, and both rates of 1,3-D (Table 1). Chitin-urea products may serve as a slow-release $\mathrm{N}$ fertilizer (Spiegel et al., 1988), which may have helped stand establishment in the present studies. Fosthiazate increased marketable fruit yield relative to the control (Table 1), indicating a potential benefit. Aldicarb reduced preharvest nematode populations relative to the control, but aldicarb did not result in a significant fruit yield increase (Table 1).

Chitin-urea was the only treatment to produce a net increase in nematode counts from preplant to preharvest in all three years (data not presented). This finding helps explain why the increased stands in chitin-urea plots did not result in increased marketable fruit yields. While chitin-urea products frequently have shown nematicidal activity, they may be less effective than standard materials such as 1,3D (Sipes et al., 1999) or even ineffective (Johnston, 1990). Another drawback is the high rate of application recommended for these products (at least $2.2 \mathrm{Mg} \cdot \mathrm{ha}^{-1}$ ).

A preplant nematode count of 23 is considered potentially damaging for peppers, and treatment may be worthwhile (personal com- munication, K.R. Barker, North Carolina State Univ.). Although fosthiazate was promising, nematicide treatments were of limited benefit under the conditions of these studies.

\section{Literature Cited}

Ayoub, S.M. 1980. Plant nematology, an agricultural training aid. Revised ed. NemaAid Publications, Sacramento, Calif.

Johnston, S.A. 1990. Evaluation of soil fumigants/ nematicides for root-knot nematode control in carrots. Fungicide and Nematicide Tests 45:154.

SAS Institute. 1999. SAS/STAT user's guide, version 8. SAS Inst., Cary, N.C.

Sipes, B.S., A.S. Arakaki, D.P. Schmitt, and R.T. Hamasaki. 1999. Root-knot nematode management in tropical cropping systems with organic products. J. Sustainable Agr. 15:69-76.

Spiegel, Y., U. Kalkafi, and E. Pressman. 1988. Evaluation of a protein-chitin derivative of crustacean shells as a slow-release nitrogen fertilizer on Chinese cabbage. J. Hort. Sci. 63:621-628. 